\title{
THE EFFECT OF COMMONLY USED PESTICIDE ON THE SEED GERMINATION, PLANT VIGOR AND PHOTOSYNTHETIC PIGMENT BRINJAL (SOLANUM MELONGENA L.)
}

\author{
Ganesh Nikam ${ }^{1}$ Mukul Barwant ${ }^{2}$ \\ Department of Botany, Arts Commerce and Science College Sonai 1 \\ Department of Botany, R.B.N.B. College Shrirampur 2 \\ Email: mukulbarwant97@gmail.com, ganeshnikam7262@gmail.com
}

\begin{abstract}
:
The brinjal (Solanum melongena) it is one most widely used vegetable crop in many countries. It is important vegetable growing in all season with rich nutritive value. During the plant growth different insect and pest are attacking on the plant during which we used different insecticide and pesticide. Pesticide are group of chemical which suppress growth pest and animal and protect the agricultural product. Some commonly used pesticide is Neon and Chloropyrifos having effect on the germination and plant growth. In the present study, the effect of over application of two commonly used pesticides (Neon and Chloropyrifos) was evaluated on the germination, seedling vigor and photosynthetic pigments in brinjal The obtained results revealed that seed germination was decreased by the pesticides. All the tested pesticides reduced the growth of brinjal when applied in higher concentration than the recommended dose, but at lower doses the pesticides had some stimulatory effects on growth as compared to the control. Same effect occurs in Root and Shoot length as dose will increase than the recommendation then root and shoot length will be decrease while when reduced the dose of pesticide then root and shoot length will be increase . A similar effect of pesticides was observed on the photosynthetic pigments, i.e. a decrease in pigments concentrations was caused at higher doses but an increase was observed at lower doses of pesticides.
\end{abstract}

Key words: - Pesticides ,Phytotoxic effects, Brinjal, Chlorophyll, Germination, Root Shoot length

\section{INTRODUCTION:}

The brinjal (Solanum melongena) it is one most widely used vegetable crop in many country such as Central south, East Asia some parts of Africa and Central America (Harish et al 2011) . It is native of India and grown throughout country (Chaudhari 1970 pareet 2006) It is important vegetable growing in all season with rich nutritive value consisting minerals like Iron, Phosphorous, Calcium and Vitamin Like A, B, C due to which unripe fruit is used vegetable in country. It is also used as raw material for pickle making (Singh et al 1963).It has reported that those suffering from diabetes that person used as medicine. It is bushy plant ,commonly known as egg plants it belongs to family solanaceae .It is one most popular and important vegetable grown in Bangladesh and most of parts of India It is native of Indian sub - continent with probable origin of India .brinjal is the second most important vegetable crops after potato in relation to its total production (Anonymous 1996).The fruit is large pendant, berry or oblong in shape and smooth texture. It has been cultivated in kitchen garden in Bangladesh from time immemorial and grown in summer and winter .Brinjal is well known source of carbohydrate ,protein, minerals and vitamin .It is good source of dietary fiber and folic acid and low saturated fatty acid cholesterol and sodium (FAO ,1995).Composition per 100 gm of edible portion of brinjal is 24.0 calories and moisture content $97.7 \%$ carbohydrate $4.0 \%$ protein 1.4 $\mathrm{gm}$,fat $0.39 \mathrm{gm}$ fiber $1.3 \mathrm{gm}$, vitamin $\mathrm{A}, 124.0$ I.U.,Oxalic acid $18.0 \mathrm{mg}$, iron $0.38 \mathrm{mg}$ vitamin 
C $12 \mathrm{mg}$ (Anonymous 2007) . It was studied that different classes of organophosphate has found in vegetable the mean concentration of Chloropyrifos in eggplant $(24.02 \mathrm{ug} / \mathrm{kg}$ ),cabbage (10.55 ug / kg), cauliflower (2.85 ug $/ \mathrm{kg}$ ) ,tomato (3.01ug/kg)( Sinha et al 2012). The application of chemical to the control the pathogen, insect, pest attack on the seed (Sharma et al 2015) .Although insecticidal control is one of the common means against the fruit borer, many of the insecticide are applied to are not effective in satisfactory control of this pest. Brinjal being vegetable crops, used of chemical insecticidal will leave considerable tonic residnes on the fruit. It studies that biofungicide growth regulator on seed germination such as ash gourd, ridge gourd better growth than chemical (Lakshman et al 2013) .Pesticides is group of chemical that purposely applied to the environment with an aim to suppress plant and animal pests and to protect agricultural product Use enormous quantities of pesticide also spoil the ecosystem directly or indirectly (Mozuder and Hossain 2013). It was studied that organic contaiminent anthracine and cloropyrifos on seed germination Lolium multiflorum has been investigated thereis no adverse effect on anthracine but chlropyrifos they show delay in germination (Korde et al 2008). It was studied the effect of two pesticide (DDT,Bourdex mixture ) on the germination and growth of plant Vigna sinesis , Oryza sativa in general both variety germination, radical elongation will increase with increasing concentration (Mendezz et al 2014). The studied seed soak with growth regulators Ergynium seed with GA3500 they maximum germination (Mozumder 2016). The used of fungicide is harmful or useful to decide some parameter will determine that are germination percentage shoot length, vigor index, fresh weight and dry weight that is recorded increases all parameter with increasing concentration of pesticide(Airaji et al 2014) . The toxic impact of pesticide endosulphan and kitazin on the germination and enzyme activity of Solanum melogena (Sammalah et al 2011). It was investigated that debltamethrin pesticide on biological properties of maize seed exposed in environment with relevant doses all seedling character will decrease with increasing pesticide dose concentration( Durgan et al 2015) It has reported that pesticides application may decline growth and yield of vegetables by affecting the beneficial microflora of soil (Glover 2008).Chemical seed treatment are fungicide or insecticide applied on the seed to control disease of seed and seedling.

\section{Aim and objective}

- To study the effect of pesticide (Nuwan \& Chloropyrifos ) on seed germination percentage of brinjal

- To determine effect of pesticide on root and shoot length

- To study effect of pesticide on chlorophyll content of leaf

\section{MATERIAL \& METHODS:}

\section{Collection of seed :}

Seeds of Brinjal are collected from certified dealer in Srirampur city at 30th November 2016 .the variety is Ajit -111 which used in hybridization programmed, in the experiment.

\section{Sterilization :}

Seed of Brinjal is surface sterilized with $0.1 \%$ mercuric chloride solution $\left(\mathrm{Hgcl}_{2}\right)$ thoroughly the distilled water three times.

\section{Pesticide Solution:}

The healthy seeds of brinjal was treated with different concentration of Nuwan and Chloropyrifos such as control , $0.1 \%, 0.4 \%, 0.7 \%, 1 \%$.

\section{Determination of germination}

The germination of seeds was observed at different intervals for 07 days. A seed was 
considered to be germinated if its radicle was emerged. The germination percentage was calculated from the number of total seeds and germinated seeds in a Petri plate.

\section{Determination of roots and shoots length} after 20 days of growth, seedlings were separated into roots and shoots and their length was measured in centimeter $(\mathrm{cm})$ with the help of a measuring tape.

Determination of photosynthetic pigments : For determination of photosynthetic pigments (chlorophyll a, b and total chlorophyll), $25 \mathrm{mg}$ of dried plant material was taken in a test tube and $25 \mathrm{mg}$ of $\mathrm{MgO}$ was added to prevent the formation of pheophytin. Total photosynthetic pigments were determined calorimetrically by the method recommended by METZNER et al. (1965) A $5 \mathrm{ml}$ of methanol was added in each sample and homogenized on shaker for $2 \mathrm{~h}$ followed by centrifugation for $5 \mathrm{~min}$ at 4000 rpm. After centrifugation, the supernatant was transferred to a $1-\mathrm{cm}$ path length cuvette. The absorbance was measured using methanol solvent as a blank in a UV-Vis spectrophotometer at three different wavelengths: 666, 653 and $470 \mathrm{~nm}$. Chlorophyll a, b and total Chlorophyll were calculated according to the method of Lichtenthaler and Wellburn (1983) as follow:

Ca 1/4 15:65 OD666_7:340 OD653

$\mathrm{Cb}$ 1/4 27:05 OD653_11:21 OD666

Cxpc $\quad 1 / 4 \quad$ ð1000 OD470_2:860 Ca_129:2 $\mathrm{CbP}=245$

where $\mathrm{Ca}, \mathrm{Cb}$ and $\mathrm{Cx}$ ?c represent the concentration of chlorophyll $\mathrm{a}, \mathrm{b}$ and total chlorophyll, respectively while OD shows optical density (absorbance) at a given

Wavelength.

RESULT AND DISCUSSION:

Effect of pesticides on seed germination
The effect of different concentrations of the tested pesticides on seed germination in brinjal is shown in Fig. $1 \mathrm{a}$ b. A significant decrease in germination of seeds was observed with the increase in concentrations of pesticides as compared to the control. The concentrations of pesticides below the recommended dose promoted the germination capacity of seeds . With the passage of time, a recovery of germination was observed; however, the germination at higher doses of pesticides was still lower in comparison to the control. The overall data on germination revealed that the effect of pesticides on seed germination was concentration and time dependent, i.e. a decrease with increasing concentration of pesticides was shown but a decrease in inhibitory effect was observed with increase in exposure time. The results of germination effect can observed two pesticides such Nuwan and Chloropyrifos at different concentration in both pesticide shows same that increase in concentration of pesticide germination percentage will decrease as compared with Control such as shown in table no 1 and table no 2

\section{Effect of pesticides on root-shoot length}

The response of root and shoot growth in brinjal seedlings was different to different pesticides (Figs. 2 -5). In case of shoot, the highest reduction in length was observed at Nuwan treated shows $1 \% 3.87 \mathrm{~cm}$ with average seven days interval five reading and the largest shoot length is control condition seedling after that $0.1 \%$ solution shows highest shoot length 6.12 $\mathrm{cm}$ in the root length they show same effect $1 \%$ solution shows lowest shoot length $5.4 \mathrm{~cm}$ while $0.1 \%$ shows highest after the control condition $8.4 \mathrm{~cm}$.the same results occurs in the effect of Chloropyrifos Shoot length shows highest length in $0.1 \%$ solution is $4.9 \mathrm{~cm}$ and lowest shoot length in $1 \%$ solution is $3.4 \mathrm{~cm}$ same effect will occurs in root length highest root 
length after control condition in $0.1 \%$ is 5.55 $\mathrm{cm}$ and lowest root length in $1 \%$ solution is 0.47 $\mathrm{cm}$. Overall results tell that effect of pesticide on the root and shoot length is increasing concentration of pesticide reduced in length of root and shoot

\section{Effect of pesticides on photosynthetic pigments}

The effect of pesticides on chlorophyll $a, b$ and total Chlorophyll was tested in shoot of brinjal seedlings. The adverse effect of the tested pesticides on all pigments was found to increase with the increase in concentration of pesticides. The photosynthetic pigments were more susceptible to pesticide stress than other tested end points. At lower concentrations, no significant change was found in chlorophyll a content where an increase was observed as compared to the control (Fig. 6). The response of total Chlorophyll to pesticide exposure varied and depended upon the type and concentration of pesticides used. The recommended concentrations of all the two pesticides showed no significant effect on total chlorophyll as compared to the control.

\section{CONCLUSIONS}

It can be concluded from the present study that pesticides application above the recommended dose can adversely affect brinjal growth. At higher doses, all the tested pesticides caused toxic effects on all the studied parameters of brinjal. Since pesticide dealers usually suggest farmers to apply pesticides in doses doubled to the recommended dose, it can be harmful and affect brinjal growth and yield.

The application of pesticides above the recommended dose should be discouraged. There is a need to educate pesticide dealers and farmers about the proper and optimal applications of pesticides. The effects of these pesticides on no target host plants should be further investigated at anatomical, biochemical and molecular level to identify the mechanism by which they cause toxicity in non-target plants.

\section{REFERENCES:}

Aisha Mohammad Hommad Airaji Effect of Amistar and Dithane M-45, a systematic growth parameter and antioxidative enzyme of maize (Zea mays L) Research and Review Journal of Botanical Science 2014 : $3(4) ; 13-20$

Anonymous. 1987. Regulating pesticides in food. The Delancy Paradox. National Academy Press,Birch C.J.stephen,K.,McLean,G. Doherty,A. Hammer, G.L

Anonymous. 2003a Products and ServicesFungicides Syngenta, 2003[cited April 8 2003]. Available from http:www.syngenta.com

Anonymous. 2003b Labels and safely data sheets-Dithane M45.Dow AgroSciences, 2003 [cited April 9 2003]. Available from http:www.dowagro.com

Abdul-Baki AA and Anderson JD. Vigor determination of soybean seeds by multiple criteria. Crop Sci. 1973;13: 630-633.

Ahmed AM, Heikal MD, Hindawy OS Side effects of benomyl (Fungicide) treatments on sunflower, cotton and cowpea plants. Phyton 1983:23:185195 
Astik Kumar Buts, Divya Singh Effect of bavastin on Seed germination Morphological future and the yeild of Vigna radiate ,Indial J .L. Sci. 2013 (1) $15-20$

DL Korde and MH Fulekaee Effect of organic contaminant on seed germination of Lolium multiflorum in soil Biology and Medicine 2009: $1(1), 28-24$

DE BERTOLDT M., RAMBEILI A., GIOVANNETTI M., GRISELLI M. Effect of benomyl and captan on rhizosphere fungi and the growth of Allium cepa. - Soil Biol. Biochem. 1978:10: 265-268

Glover-Amengor M, Tetteh FM Effect of pesticide application rate on yield of vegetables and soil microbial communities.

W Afr J Appl Eco 2008:12:1-7

FAO (1995) Food and Agricultural Organization Stat, core production. http:/ / faostat.fao.org/site/340/def ault.aspx

K.K.Sharma ,U.S. Singh Pankaj Ashish Kumar, Lalan Sharma Seed treatment for sustainable agriculture Journal of Applied and natural Science 2015:7(1)521-539

Lichtenthaler HK, Wellburn AR Determinations of total carotenoids and chlorophylls $\mathrm{a}$ and $\mathrm{b}$ of leaf extracts in different solvents.
Biochem Soc Trans 1983:11:591592

Minamor AA. Effect of Two Fungicides (Caocobre and Ridomil) on Germination and Radicle Elongation of Cocoa (Theobroma Cacao L) Seedlings. Int $J$ Pure Appl Sci Technol. 2013;15(1):79-86

METZNER H., RAO H. \& SENGER H. Untersuchungen zur Synchronisier barkeit einzelner PigmentmangelMutanten von Chlorella. - Planta 1965 :65: 186-194.

Romilly Margaret ,Memdez and Bincy Manuel ,Effect on the tolerance pf Vigna sinesis L. and Oryza sativa L. to the application of pesticide, IOSR Journal of Environmental Science ,Toxicology and Food Technology $2014: 8(6), 13-14$

Rehman S, Harris PJC, and Bourne WF. Effect of pre-sowing treatment with calcium salts, Acacia seeds. J Plant Nutr. 1998;21: 277-285.

Ragbet Ezgi Durgan ,Serma Kilic, Yasemin Coskon Response of Maize ( Zea mays $L$.) to different concentration treatment of deltamethrin ,Pesticide Biochemistry and Physiology 2015 :24,15-20

Sukesh Narayan Sinha ,M. Vishnu Vardhan Rao , K. Vasudev, ,Distribution of pesticide in different commonly vegetable from Hyderabad India , Food Research International ,2012:45(1),161-169 
Shyamsundar S. Lakshaman, Chandan K. Mondal , Bhaskar Mukharjee, Response of bio-inoculant to early seedling growth in Ash gourd and Ridge gourd ,Esci.J. Crop Production ,2013:2(1),31-36

S.N. Mozumder ,m.m. Hossain and S.Akter Influence of seed treatment and priming on growth performance of Eryngium foetidum, International Journal of Advance research in Biological Science 2016;3(6);113122

T.A.S. Aveling, V. Goveder, D.S. Kandolo and Q. Kirts Inger, the Effect of treatment of selected pesticide on the viability and the vigour of maize (Zea mays L) and seedling emergence in presense of Fusarium graminerarum ,Journal of Agricultural Science 2013:151:474481

Tetrazolium-Verfahren [The 'vigour' of seeds and its determination by the topographical terazolium method]. Saatgutwirtschaft 2:37-41.

WENSLEY R. N. Effect of benomyl and two related systemic fungicides on growth of fusarium wilt-susceptible and resistant muskmelon. - Can. J. Plant Sei. 1972:52: 775—779. 
Table no 1

\begin{tabular}{|l|l|l|l|l|}
\hline \multicolumn{1}{|c|}{ Sr no } & Concentration & $\begin{array}{c}\text { Germinated } \\
\text { seed }\end{array}$ & Total seed & $\begin{array}{c}\text { Germination } \\
\text { Percentage }\end{array}$ \\
\hline 1 & Control & 15 & 20 & $75 \%$ \\
\hline 2 & $0.1 \%$ & 13 & 20 & $65 \%$ \\
\hline 3 & $0.4 \%$ & 18 & 20 & $90 \%$ \\
\hline 4 & $0.7 \%$ & 09 & 20 & $45 \%$ \\
\hline 5 & $1 \%$ & 07 & 20 & $35 \%$ \\
\hline
\end{tabular}

Table no 2

\begin{tabular}{|l|l|l|l|l|}
\hline Sr no & Concentration & $\begin{array}{l}\text { Germinated } \\
\text { seed }\end{array}$ & Total seed & $\begin{array}{l}\text { Germination } \\
\text { Percentage }\end{array}$ \\
\hline 1 & Control & 15 & 20 & $75 \%$ \\
\hline 2 & $0.1 \%$ & 16 & 20 & $80 \%$ \\
\hline 3 & $0.4 \%$ & 17 & 20 & $85 \%$ \\
\hline 4 & $0.7 \%$ & 14 & 20 & $70 \%$ \\
\hline 5 & $1 \%$ & 10 & 20 & $50 \%$ \\
\hline
\end{tabular}

Root and Shoot length

Table no 3

\begin{tabular}{|l|l|l|l|l|l|l|l|}
\hline Sr no & Concentration & \multicolumn{6}{|l|}{ Root length } \\
\hline & & 1 & 2 & 3 & 4 & 5 & Total \\
\hline 1 & Control & 9.2 & 6.4 & 7.2 & 5.3 & 28.1 & 7.02 \\
\hline 2 & $0.1 \%$ & 8.2 & 8.5 & 9.2 & 8.7 & 34.6 & 8.65 \\
\hline 3 & $0.4 \%$ & 6.5 & 4.2 & 3.2 & 1.2 & 15.1 & 3.77 \\
\hline 4 & $0.7 \%$ & 5.2 & 4.1 & 3.5 & 0.8 & 13.6 & 3.40 \\
\hline 5 & $1 \%$ & 7.6 & 6.5 & 4.5 & 3.2 & 21.8 & 5.45 \\
\hline
\end{tabular}

Table no 4

\begin{tabular}{|l|l|l|l|l|l|l|l|}
\hline Sr no & Concentration & \multicolumn{6}{|l|}{ Shoot length } \\
\hline & & 1 & 2 & 3 & 4 & 5 & Total \\
\hline 1 & Control & 9.7 & 8.2 & 7.5 & 6.2 & 31.6 & 7.90 \\
\hline 2 & $0.1 \%$ & 7.9 & 9.2 & 3.1 & 4.3 & 24.5 & 6.12 \\
\hline 3 & $0.4 \%$ & 4.8 & 4.7 & 3.9 & 4.9 & 18.3 & 4.57 \\
\hline 4 & $0.7 \%$ & 4.5 & 6.3 & 5.4 & 3.7 & 19.9 & 4.97 \\
\hline 5 & $1 \%$ & 4.2 & 3.8 & 2.7 & 4.8 & 15.5 & 3.87 \\
\hline
\end{tabular}


Table no -5

\begin{tabular}{|l|l|l|l|l|l|l|l|}
\hline Sr no & Concentration & \multicolumn{6}{|l|}{ Root length } \\
\hline & & 1 & 2 & 3 & 4 & 5 & Total \\
\hline 1 & Control & 7.5 & 8.5 & 6.2 & 8.4 & 7.65 & 7.65 \\
\hline 2 & $0.1 \%$ & 4.9 & 5.1 & 5.0 & 7.2 & 5.55 & 5.55 \\
\hline 3 & $0.4 \%$ & 0.4 & 0.7 & 1.0 & 0.2 & 0.57 & 0.57 \\
\hline 4 & $0.7 \%$ & 0.3 & 0.72 & 0.5 & 0.6 & 0.40 & 0.40 \\
\hline 5 & $1 \%$ & 0.5 & 0.7 & 0.3 & 0.4 & 0.47 & 0.475 \\
\hline
\end{tabular}

Table no 6

\begin{tabular}{|l|l|l|l|l|l|l|l|}
\hline Sr no & Concentration & \multicolumn{6}{|l|}{ Shoot length } \\
\hline & & 1 & 2 & 3 & 4 & 5 & Total \\
\hline 1 & Control & 8.5 & 7.3 & 4.5 & 5.5 & 20.8 & 5.20 \\
\hline 2 & $0.1 \%$ & 6.5 & 5.4 & 4.3 & 3.5 & 19.7 & 4.92 \\
\hline 3 & $0.4 \%$ & 5.3 & 4.7 & 4.2 & 3.2 & 17.4 & 4.35 \\
\hline 4 & $0.7 \%$ & 4.5 & 3.7 & 4.9 & 2.8 & 15.9 & 3.97 \\
\hline 5 & $1 \%$ & 4.3 & 3.7 & 2.8 & 3.1 & 13.99 & 3.47 \\
\hline
\end{tabular}

Table no 7

\begin{tabular}{|l|l|l|l|l|}
\hline Sr no & Concentration & $\begin{array}{l}\text { Chl a } \\
\text { gm tissue }\end{array}$ & $\begin{array}{l}\text { Chl b } \\
\text { gm tissue }\end{array}$ & $\begin{array}{l}\text { Total Chl/ } \\
\text { gm tissue }\end{array}$ \\
\hline 1 & Control & 0.8978 & 0.9785 & 1.849 \\
\hline 2 & $0.1 \%$ & 1.5110 & 2.1703 & 1.9872 \\
\hline 3 & $0.4 \%$ & 2.3517 & 1.7426 & 1.6501 \\
\hline 4 & $0.7 \%$ & 2.4638 & 2.1069 & 1.9769 \\
\hline 5 & $1 \%$ & 1.1675 & 1.4248 & 1.3625 \\
\hline
\end{tabular}

Tables : Table no 1 Nuwan Pesticide Treatment, Table no 2 Chloropyrifos Pesticide Treatment ,Table no 3 Nuwan Pesticide Treatment Root length, Table no 4 Nuwan Pesticide Treatment Shoot length ,Table no 5 Chloropyrifos Pesticide Treatment root length ,Table no 6 Chloropyrifos Pesticide Treatment Shoot length, Table no 7 Chlorophyll estimation of treated seedling 
I J R B A T, Issue (VIII), Vol. III, Sept 2020: 01-10 A Double-Blind Peer Reviewed \& Refereed Journal
OPEN $\bigcirc$ ACCESS

Original Article

Fig no 1 (a)

25

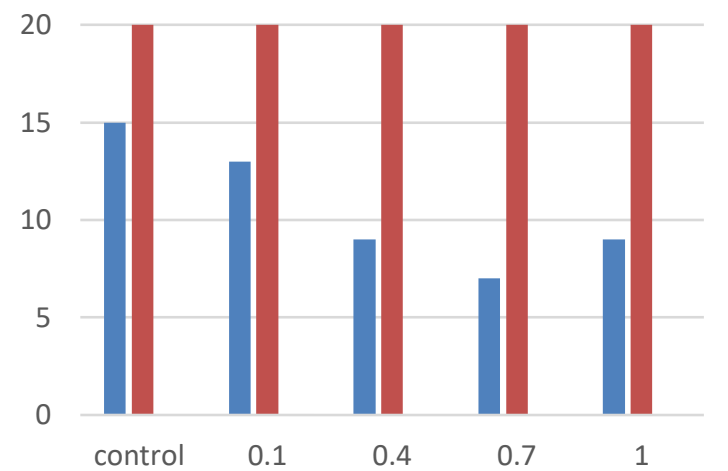

घerminated seed $\quad$ total seed $\quad$ Column1
Fig no 1(b)

25



n Germinated seed $\quad$ Total seed Column1
Fig no 2

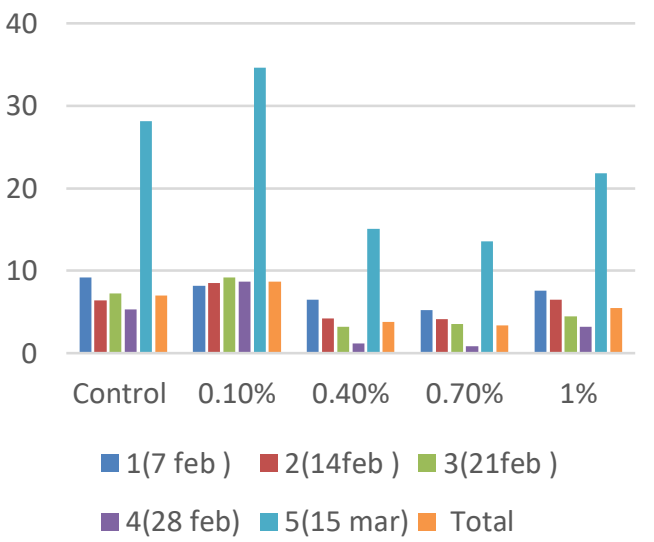

Fig no 4

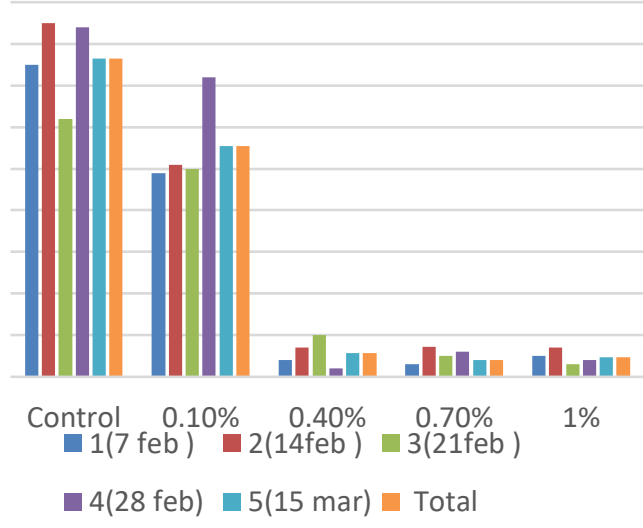

Fig no -3

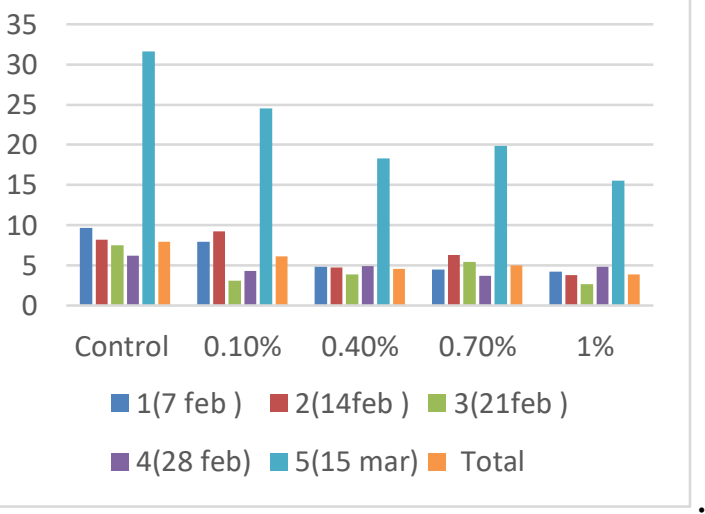

Fig no 5






\section{Fig no 6}

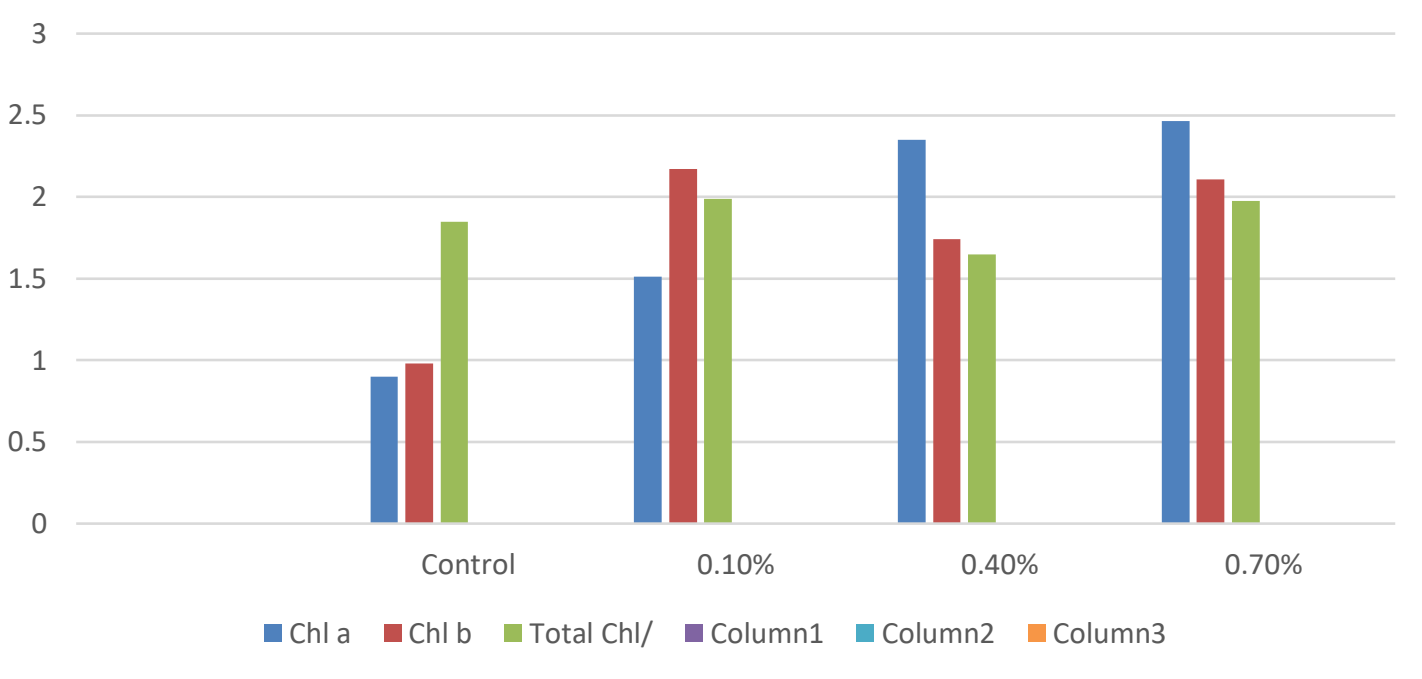

Figure - Fig no 1 (a) Nuwan Pesticide Treatment Germination Percentage, Fig no 1 (b) Chloropyrifos Pesticide Treatment germination percentage, Fig no 2 Nuwan Pesticide Treatment Root length, Fig no3 Nuwan Pesticide Treatment Shoot length , Fig no 4 Chloropyrifos Pesticide Treatment root length, Fig no 5 Chloropyrifos Pesticide Treatment Shoot length, Fig no 6 Chlorophyll estimation of treated seedling 